\title{
Suicidal deaths by burns in females of reproductive age: 2 yr study
}

\author{
Shashikant Vithobaji Dhoble ${ }^{1,5^{*}}$, Rajesh Chandrabhan Dere ${ }^{2}$, Arun Kumar Jaiswani ${ }^{3}$ \\ and Ramesh Rangrao Savardekar ${ }^{4}$
}

\begin{abstract}
Background: In India, deaths related to burns are more common in women than in men. Fire is easily available weapon used by female for suicide. Most burns happen in low- and middle-income countries.

Aim: The current study was conducted with an objective to find out Socio demographic profile \& the causes of suicidal deaths in females by burns and the various reasons associated with them.

Study design: A prospective study for 2 year period done in tertiary care health center in metropolitan city.

Results: In this study (67.19\%) victims belonged to lower middle class, Hindu (75\%). Housewives (71.88\%), Married (70. 31\%) females, educated upto high school (34.38\%), belonged to urban area (54.69\%). Age group 14-25 years was more common affected (59.38\%), married since more than 7 years (28.13\%), victims survived for period of 1-7 days (57.81\%). Suicidal burns were most commonly by self \& unknown reasons (70.31\%) \& victims sustained $51-100 \%$ TBSA burns (87. 5\%), died from Septicemia (68.75\%).

Conclusion: Most common married, housevies, belonged to young age were victims of Suicidal burn injury. Considering the morbidity and mortality owing to burns, government and other social organizations need to put special efforts for the prevention and education programs against Suicide.
\end{abstract}

Keywords: Burn, Suicide, Females, Septicemia

\section{Background}

Fire is easy and dangerous weapon in kitchen to be used for suicide for females in developing country like India. Females in India are suffering from torture since birth in every ways for gender discrimination to career and partner choosing option and it continues at their in laws families too.

Females at home can find a fire as weapon to end their lives instead of suffering in male dominated societies. In India Burns deaths are more common in females though accidental are leading (as per history given by investigating agencies) but suicide by burns in females should also be taken into consideration.

Nonaccidental deaths of young women - dowry deaths, bride burning - have long been a concern in India. They

\footnotetext{
*Correspondence: shashichandrapur@gmail.com; svdfmt@gmail.com ${ }^{1}$ Department of Forensic Medicine, Govt. Medical College, Chandrapur, India ${ }^{5}$ s/o Vithoba N Dhoble, At. Post. Ta. Parseoni, Nagpur, Maharashtra 441105, India

Full list of author information is available at the end of the article
}

are considered most likely to occur within 7 years of marriage and may be overtly homicidal or the result of suicide as a consequence of coercion or desperation. The suicide of a young woman within 7 years of marriage is considered suspect and her husband or in-laws may be held accountable (Daruwalla et al., 2014).

Many cultural and socio-economic factors of a country are responsible for the causation of such deaths in females. According to WHO (2000) report, 238,000 individuals died of fire related deaths and $95 \%$ of these deaths occurred in low and middle income countries (WHO Report 2000, n.d.).

A significant number of deaths in India occur due to burns every year and over 10,00,000 people are moderately or severely burnt every year in this country (Burns, n.d.).

The present study has been taken up to assess the female suicidal deaths by burns in metropolitan city of the country and factors associated with such female suicidal burns. The aim of the study is to analyze the various socio epidemiological and medico-legal aspects in the 
community which will help to plan the treatment \& preventive programme for reducing the incidence of suicide in female by fatal burns injuries.

\section{Aims and objectives}

The aim of the study is to describe the socio-demographic profile of suicidal burn injury in the mortuary situated in the metropolitan city of India. In the present study, an attempt is made to analyze the data statistically collected on such cases, with the objective to highlight various aspects of so-called Suicidal fatal burns in females.

\section{Material \& methods}

This is a 2 years Prospective study, based on autopsy analysis conducted in the Department of Forensic Medicine \& Toxicology, in tertiary health care center in metropolitan city, during 1st August 2012 to 31st July 2014. Ethics committee approval had been taken. In this period female in the reproductive age group i.e. 1440 yr. who sustained burn injury were selected and total 270 autopsies of burns females were conducted, out of that 64 female cases were brought with the alleged history of Suicidal burn injuries. On basis of autopsy studied in detail including age, period of survival, percentage of burn injuries, cause of death, etc. history was recorded from the police, relatives of deceased and friends. All findings are depicted in tabular form and inference is extracted.

\section{Observations \& results}

Out of the total unnatural female deaths and autopsies conducted during this study period, 270 females burns cases of the age group of 14-40 years were collected. Out of which 64 cases were of suicidal females which were died by burns injury, their data analyzed and tabulated.

Table 1 Described Socio demographic profile of victims. Most of the victims (67.19\%) belonged to lower middle class followed by upper lower class (21.88\%). Most common victim were Hindu i.e. (75\%). Most of the females were married i.e. (70.31\%). Most of victims of this study had educated upto High school (34.38\%) followed by middle school (21.88\%). urban females were common i.e. $(54.69 \%)$ which included population in this metropolitan city region followed by Suburban residential victims involved i.e. (45.31\%) which belonged to periphery of this metropolitan city etc.

Table 2 showed that Female victims of Age group 1420 yr. (29.69\%) and $21-25$ yr. (29.69\%) were equally affected followed by $31-35$ years (18.75\%) involved in Suicidal burns. Out of all married females, most of victims were married since more than 7 years i.e.(28.13\%) followed by less than 2 years i.e..(26.56\%). Housewives

Table 1 Socio Demographic profile of Suicidal burns females

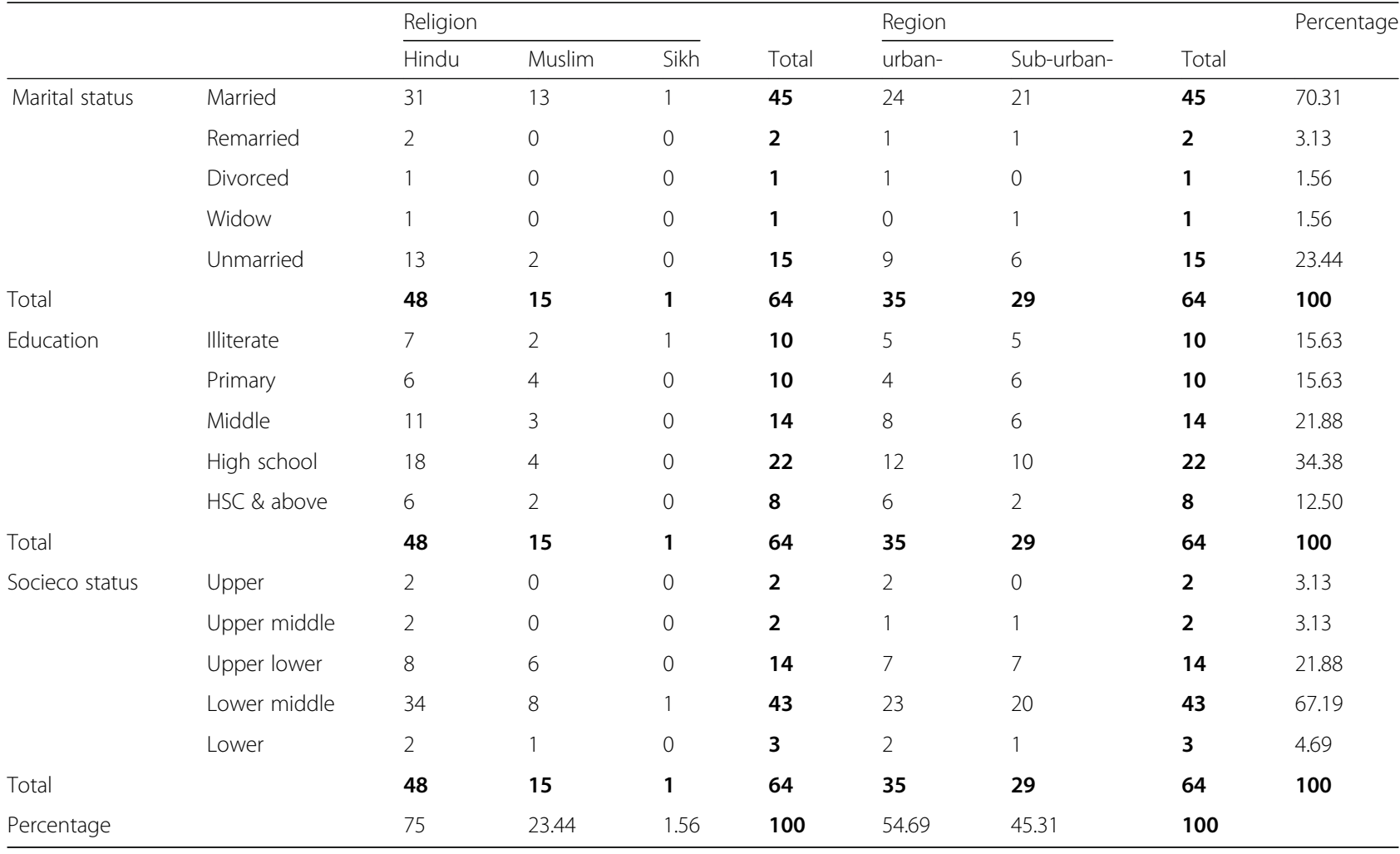


Table 2 Age and occupation wise duration of marriage and dowry case filed

\begin{tabular}{|c|c|c|c|c|c|c|c|c|c|c|c|}
\hline & & \multicolumn{5}{|c|}{ Married Since } & \multirow[t]{2}{*}{ Total } & \multicolumn{2}{|c|}{ Dowry case } & \multirow[t]{2}{*}{ Total } & \multirow[t]{2}{*}{ Percentage } \\
\hline & & Not Apply & less than $2 \mathrm{yr}$ & $2-4 y r$ & 4-7 yr & more than $7 \mathrm{yr}$ & & case filed & no & & \\
\hline \multirow[t]{5}{*}{ Age } & $14-20 \mathrm{yr}$ & 11 & 7 & 1 & 0 & 0 & 19 & 7 & 12 & 19 & 29.69 \\
\hline & $21-25 \mathrm{yr}$ & 3 & 6 & 3 & 5 & 2 & 19 & 12 & 7 & 19 & 29.69 \\
\hline & $26-30 \mathrm{yr}$ & 0 & 3 & 1 & 2 & 4 & 10 & 3 & 7 & 10 & 15.63 \\
\hline & $31-35 \mathrm{yr}$ & 1 & 1 & 0 & 2 & 8 & 12 & 2 & 10 & 12 & 18.75 \\
\hline & $36-40 \mathrm{yr}$ & 0 & 0 & 0 & 0 & 4 & 4 & 0 & 4 & 4 & 6.25 \\
\hline Total & & 15 & 17 & 5 & 9 & 18 & 64 & 24 & 40 & 64 & 100 \\
\hline \multirow[t]{4}{*}{ Occupation } & Housewife & 0 & 16 & 5 & 8 & 17 & 46 & 22 & 24 & 46 & 71.88 \\
\hline & Student & 11 & 1 & 0 & 0 & 0 & 12 & 1 & 11 & 12 & 18.75 \\
\hline & Unemployed & 4 & 0 & 0 & 0 & 0 & 4 & 0 & 4 & 4 & 6.25 \\
\hline & Employed & 0 & 0 & 0 & 1 & 1 & 2 & 1 & 1 & 2 & 3.13 \\
\hline Total & & 15 & 17 & 5 & 9 & 18 & 64 & 24 & 40 & 64 & 100 \\
\hline Percentage & & 23.44 & 26.56 & 7.81 & 14.06 & 28.13 & 100 & 38 & 63 & 100 & 156 \\
\hline
\end{tabular}

(71.88\%) were most common victims of suicidal burns injury. Four victims were pregnant at time of death \& all belonged to housevies while dowry case had been filled on $24(38 \%)$ cases.

In Table 3 denotes that most of the victims survived for period of $1-7$ days (57.81\%). Followed by more than 7 days (25\%). Most of victims committed suicide burns injuries by self with reason could not be revealed i.e. (70.31\%) followed by for the reason of torture at in laws families (20.31\%). Total body surface area involved in burns of the victims noted $51-75 \%$ burns (43.75\%) cases and $76-100 \%$ burns (43.75\%) cases affected equally, while most common victims were died because of Septicemia (68.75\%) followed by Shock (17.19\%).

\section{Discussion}

Suicide for females is easy to be committed by using kitchen weapons or fire burns which is mostly commonly seen in housevies who used to live home alone when head of the family leaves home for bread and butter.

Most common victim were Hindu i.e. (75\%). Pathak and Sharma (2010) showed that most common religion was Hindu consisted 398 (82.91\%).

In our study Most of victims of this study had educated upto high school (34.38\%) followed by middle school (21.88\%). Gadage et al. (2014) concluded that most victims had middle school level of education (31.6\%) while Gupta et al. (2012) showed that the most of cases had done their education upto primary school level (49.2\%).

In present study Most of the victims (67.19\%) belonged to lower middle class followed by upper lower class (21.88\%). Memchoubi \& Nabachandra (2007) (53.84\%), Vaghela et al. (2012) (46.58\%) showed that most of cases were in low socio economic status.

In this study Most of the females were married i.e. (70.31\%). The findings were in accordance with the

Table 3 Period of survival \& cause of Suicide wise cause of Death \& percentage of burns

\begin{tabular}{|c|c|c|c|c|c|c|c|c|c|c|}
\hline & \multicolumn{5}{|l|}{ Cause of death } & \multicolumn{4}{|c|}{ Percentage of Burns on total body surface area } & \multirow[t]{2}{*}{ Percentage } \\
\hline & & Septicemia & Hypovolemia & Shock & Total & $26-50 \%$ & $51-75 \%$ & $76-100 \%$ & Total & \\
\hline \multirow[t]{4}{*}{ Period of survival } & less than $6 \mathrm{~h}$ & 1 & 4 & 1 & 6 & 0 & 2 & 4 & 6 & 9.38 \\
\hline & $6-24 \mathrm{~h}$ & 2 & 2 & 1 & 5 & 0 & 2 & 3 & 5 & 7.81 \\
\hline & 1-7 days & 26 & 2 & 9 & 37 & 5 & 12 & 20 & 37 & 57.81 \\
\hline & more than 7 days & 15 & 1 & 0 & 16 & 3 & 12 & 1 & 16 & 25.00 \\
\hline Total & & 44 & 9 & 11 & 64 & 8 & 28 & 28 & 64 & 100 \\
\hline \multirow[t]{3}{*}{ Cause of suicide } & Self & 29 & 8 & 8 & 45 & 6 & 16 & 23 & 45 & 70.31 \\
\hline & In law torture & 10 & 1 & 2 & 13 & 1 & 9 & 3 & 13 & 20.31 \\
\hline & Domestic quarrel & 5 & 0 & 1 & 6 & 1 & 3 & 2 & 6 & 9.38 \\
\hline Total & & 44 & 9 & 11 & 64 & 8 & 28 & 28 & 64 & 100 \\
\hline Percentage & & 68.75 & 14.06 & 17.19 & 100 & 12.5 & 43.75 & 43.75 & 100 & \\
\hline
\end{tabular}


studies of Vaghela et al. (2012), Buchade et al. (2011), Pathak \& Sharma (2010), Pandey \& Chaurasia (2014).

Urban females were common i.e. (54.69\%) followed by Suburban residential victims involved i.e. (45.31\%).

Our study showed that Female victims of Age group $14-20$ yr. (29.69\%) and 21-25 yr. (29.69\%) years were equally affected followed by $31-35$ years $(18.75 \%)$ involved in Suicidal burns. This is the productive age and they are generally active and exposed to stress related to carrier, workplace and also at in laws families.

These findings and reasoning were consistent with that of Pathak \& Sharma (2010), and Buchade et al. ( 2011). As per Dere \& Rajoo (2011) most common age group involved was $26-30$ years $(24.53 \%)$ followed by $21-25$ years (21.93\%). Zanzad \& Godbole (2007) showed peak incidence in age $21-30$ years (39.5\%). Gadage et al. (2014) found that $68 \%$ cases were in age $21-40$ years. Pandey \& Chaurasia (2014) revealed same that predominant age group was 21-30years (45.13\%). While Vaghela et al. (2012) study most common vulnerable group was 2130 years i.e. 344 (33.7\%). Gupta et al. (2012) found that most common group was in age $15-30$ years $(59.6 \%)$.

Out of all married females most of victims were married since more than 7 years i.e.(28.13\%).

Housewives (71.88\%) suffered most common victims of suicidal burns injury while Gadge et al. (2014) and Chawla et al. (2010) concluded that most common victims were housewives i.e. 179 (57.6\%) and 28 (56\%) respectively.

Out of total victims 4 (6.25\%) were pregnant at time of Suicidal death by burns.

This study denotes that most of the victims survived for period of $1-7$ days i.e. (57.81\%). Followed by more than 7 days i.e. (25\%). This finding consistent with studies of Zanzad \& Godbole (2007) found that most of victim survived upto 1-2 weeks after the sustaining the burns injury (21.7\%) while Gadge et al. (2014) showed most common period of survival was 4-7 days (29.9\%).

The reason for suicide in females remained unknown (70.31\%) followed by torture at in law families (20.31\%). This finding not consistent with following studies as present study was done on purely suicidal burns deaths.

Chawla et al. (2010) found stove burst were most common cause of burns. The study of Ghaffar et al. (2008) found that kerosene stove burns were most common (32.3\%). While Zanzad \& Godbole (2007) found kerosene burns $(33.2 \%)$ followed by clothes catching fire (31.9\%) were most common in female victims. Gadge et al. (2014) denoted that fall of lamp in (48.2\%) cases followed by Kerosene stove burns (29.6\%) cases.

In present study most of the victims sustained $51-75 \%$ burns (43.75\%) and $76-100 \%$ burns (43.75\%) affected equally, while most common victims were died because of Septicemia (68.75\%) followed by Shock (17.19\%).
Buchade et al. (2011) showed most of victims sustained 51 to $75 \%$ burns (56.12\%) while Zanzad \& Godbole (2007) showed $(41.4 \%)$ of $>80 \%$ burns which were more common in female victims. Gadge et al. (2014) found that cases of burns involving body surface area $80-100 \%$ were most common (51.4\%). Memchoubi \& Nabachandra (2007) found that (73.84\%) cases involved in $>80 \%$ of burns. Chawla et al. (2010) showed 91-100\% burns cases were most common (32\%). Only study of Ghaffar et al. (2008) where burns upto $25 \%$ was most common (32.5\%) followed by 26 to $50 \%$ burns (28.8\%) was most commonly affected the burns victims.

\section{Conclusion \& recommendations}

Most of the victims belonged to lower middle class and Hindu in religion, married, housewives with education upto high school, affected more commonly from urban area around this metropolitan city. Most common victims belonged to Age group 14-25 years involved in suicidal burns. Most of the victims were married since more than 7 years. Victims who were pregnant at time of death all belonged to housevies.

Most of the victims survived for period of 1-7 days and sustained burns injuries by self and unidentified reason, Most of the victims sustained $51-100 \%$ burns over body surface area while Septicemia were most common cause of death.

Though high urbanization in metropolitan city like Mumbai, rural population specially married females in reproductive age group are still at risk of stress leading to suicide burns injuries at their home. Lower middle class is more likely to suffer suicidal burns injury.

Steps should be taken not only to minimize burn mortality but also to prevent and reduce their incidence at least in cases where human error and human greed plays a role.

Government and Non Government organization should start the "stress free programme \& Meditation for depression free life" for citizen living stress and depression. More stringent laws should be implemented which would take care of the torture of housewives by their husbands and In-laws.

The purpose of the present study was to analyse the present situation of Burns female deaths in Mumbai as compared to that of other cities in India and to find out the possibilities of decreasing the incidences of female deaths by Suicidal burns in the state.

\footnotetext{
Acknowledgements

I would like to thank my teachers and Professor in Department of Forensic Medicine and Toxicology at LTMMC \& LTMGH, Sion, Mumbai for their precious guidance and support.
}

Funding

Not applicable. 


\section{Availability of data and materials}

The data used and/or analyzed in this study are available from the corresponding author on reasonable request.

\section{Authors' contributions}

SVD carried out the study, participated in the sequence alignment and drafted the manuscript and performed the statistical analysis, observations and results. RCD participated in the design of the study. AKJ participated in the data collection. RRS participated in its design and coordination and helped to draft the manuscript. All authors read and approved the final manuscript.

\section{Ethics approval and consent to participate}

Approval from Institutional Ethics committee i.e. "Staffs and Research Society, LTMMC \& LTMGH, Sion, Mumbai" has been obtained.

\section{Consent for publication}

Not applicable.

\section{Competing interests}

The authors declare that they have no competing interests.

\section{Publisher's Note}

Springer Nature remains neutral with regard to jurisdictional claims in published maps and institutional affiliations.

\section{Author details}

'Department of Forensic Medicine, Govt. Medical College, Chandrapur, India. 2Department of Forensic Medicine, Seth GSMC \& KEM Hosp, Parel Mumbai, India. ${ }^{3}$ Department of Forensic Medicine, Govt. Medical College, Nagpur, India. ${ }^{4}$ Department of Forensic Medicine, LTMMC \& LTMGH, Sion, Mumbai, India. ${ }^{5}$ s/o Vithoba N Dhoble, At. Post. Ta. Parseoni, Nagpur, Maharashtra 441105, India.

Received: 28 June 2017 Accepted: 22 December 2017

Published online: 09 January 2018

\section{References}

Buchade D, Kukde H, Dere R, Savardekar R (2011) Pattern of burns cases brought to morgue, Sion hospital, Mumbai: a two year study. J Indian Acad Forensic Med 33(4):311-312

Burns. World health Organization. Available from: http://www.who.int/ mediacentre/factsheets/fs365/en/. Last accessed Nov 11; 2014

Chawla R, Chanana A, Rai H, Aggarwal AD, Singh H, Sharma G (2010) A two year burns fatality study. J Indian Acad Forensic Med 32(4):292-297

Daruwalla N, Belur J, Kumar M, Tiwari V, Sarabahi S, Tilley N, Osrin D (2014) A qualitative study of the background and in-hospital medicolegal response to female burn injuries in India. BMC Womens Health 14:142-156

Dere RC, Rajoo KM (2011) Study of unnatural deaths in females a medicolegal study at rural medical college, Loni. J Indian Acad Forensic Med 33(3):211-213

Gadge SJ, Meshram RD, Shrigiriwar MB, Kuchekar SV (2014) Epidemiological study of fatal burns cases in SVN government medical college. J Acad Ind Res 2(10):552-555

Ghaffar UB, Husain M, Rizvi SJ (2008) Thermal burn: an epidemiological prospective study. J Indian Acad Forensic Med 30(1):10-14

Gupta R, Kumar V, Tripathi SK (2012) Profile of the fatal burn deaths from the Varanasi region, India. J Clin Diagn Res 6(4):608-611

Memchoubi P, Nabachandra H (2007) A study of burn deaths in Imphal. J Indian Acad Forensic Med 29(4):131-134

Pandey SK, Chaurasia N (2014) Thermal burn: an epidemiological retrospective study. J Punjab Acad Forensic Med Toxicol 14(1):15-18

Pathak A, Sharma S (2010) The study of un-natural female deaths in Vadodara City. J Indian Acad Forensic Med 32(3):220-223

Vaghela PC, Ahir GN, Patel MH (2012) Epidemiology of fatal burn cases in G.K. General hospital, Bhuj. Natl J Commun Med 3(2):326-329

WHO Report 2000. Available from: http://www.who.int/whr/2000/en/. Last accessed 10 Nov 2014

Zanzad NP, Godbole HV (2007) Study of fatal burn cases in medico-legal autopsies. J Indian Acad Forensic Med 29(3):42-49

\section{Submit your manuscript to a SpringerOpen ${ }^{\circ}$ journal and benefit from:}

- Convenient online submission

- Rigorous peer review

- Open access: articles freely available online

- High visibility within the field

- Retaining the copyright to your article

Submit your next manuscript at $\gg$ springeropen.com 